\title{
Nutrient loaded seedlings reduce the need for field fertilization and vegetation management on boreal forest reclamation sites
}

\author{
Kaitlin M. Schott ${ }^{1,3}$ • Alia E. K. Snively ${ }^{1} \cdot$ Simon M. Landhäusser $^{1}$ • \\ Bradley D. Pinno 2
}

Received: 5 May 2015/Accepted: 11 December 2015/Published online: 17 December 2015

(C) The Author(s) 2015. This article is published with open access at Springerlink.com

\begin{abstract}
Tree seedlings loaded with nutrients during nursery production have shown increased growth and survival relative to standard seedlings upon outplanting. We examined outplanting performance of nutrient loaded and standard trembling aspen (Populus tremuloides) seedlings, along with composition and cover of competing vegetation, on a boreal oil sands reclamation site with two different soil types (forest floor mineral mix and peat mineral mix) and four different broadcast fertilizer applications [250 kg/ha immediately available fertilizer (IAF), $500 \mathrm{~kg} / \mathrm{ha}$ IAF, $670 \mathrm{~kg} / \mathrm{ha}$ controlled release fertilizer, and an unfertilized control]. Average height growth across all treatments was $19 \%$ greater for nutrient loaded aspen seedlings than standard seedlings after two growing seasons. With respect to soil types, aspen growth was greater on peat mineral mix and seedlings growing in this soil type showed a greater response to both nutrient loading and fertilization; however, this could partially be attributed to greater cover by competing vegetation on the forest floor mineral mix. In the first growing season, trees treated with immediately available fertilizer showed the greatest growth response but in the second growing season only the controlled release fertilizer application resulted in growth rates greater than the controls. Fertilizer regime had similar effects on total cover of competing vegetation, although fertilization additionally promoted increased cover of grasses in the forest floor mineral mix. Overall, we clearly show that nutrient loaded trembling aspen seedlings can be used to offset early field fertilization needs at forest reclamation sites.
\end{abstract}

Simon M. Landhäusser

simon.landhausser@ualberta.ca

1 Department of Renewable Resources, University of Alberta, 4-44A Earth Sciences Building, Edmonton, AB T6G 2E3, Canada

2 Natural Resources Canada, Canadian Forest Service, Edmonton, AB T6H 3S5, Canada

3 Present Address: Natural Resource Conservation Service, 709 Furnas Dr, Osceola, IA 50213, USA 
Keywords Seedling quality $\cdot$ Controlled release fertilizer - Soil types $\cdot$ Plant community development · Competition · Populus tremuloides · Forest land reclamation · Nutrient availability

\section{Introduction}

The successful restoration of surface-mined areas to forested lands is a challenge that must be faced in an integrative, multi-disciplinary manner. In reclaimed mine areas, resource managers have the unique ability to manipulate factors as variable as seedling stock attributes, fertilization regime, and soil capping material type to facilitate tree seedling establishment and plant community development, thereby influencing the future trajectories of reclaimed forest ecosystems (Macdonald et al. 2012; Jacobs et al. 2015). Oil sands mining in northern Alberta has disturbed approximately 84,395 ha of land between 1967 and 2012 and successfully reclaiming mined areas remains a priority with environmental regulations requiring the reclamation of land to "equivalent land capability" after mining operations cease (Alberta Government 1999).

After re-contouring of landforms, land reclamation generally involves placing a layer of suitable subsoil which is subsequently capped with a cover soil comprised of a mixture of organic matter and surface mineral soils salvaged prior to mining. The two most common types of cover soils used in this region are a forest floor-mineral mix (FFM) salvaged from upland forests sites and a peat-mineral mix (PMM) salvaged from lowland sites. Once soil placement has been completed on a site, native tree species are planted to expedite tree cover development.

Broadcast field fertilization of reclamation areas is a common practice used in an attempt to improve plant establishment and early growth (Andersen et al. 1989; Casselman et al. 2006). In a forest-reclamation stetting this can create problems as the rapid development of colonizing vegetation can compete with the planted tree seedlings (Chang and Preston 2000; Sloan and Jacobs 2013). To date, highly water soluble immediately available fertilizers (IAFs), commonly used in agriculture, are most prevalent in reclamation operations. Previous studies on reclamation sites planted with aspen seedlings have shown varied responses to IAF fertilization depending on site characteristics (Van Cleve 1973; DesRochers et al. 2003; van den Driessche et al. 2003). These fertilizers release large amounts of nutrients upon application, often resulting in nutrients being lost from the rooting zone and potentially contaminating the environment through leaching. Controlledrelease fertilizers (CRFs), which use soil temperature and a semi permeable coating to control nutrient release, have gained attention for their potential to reduce the negative effects of IAFs while still mediating nutrient limitations on harsh sites (Jacobs et al. 2005). Unlike IAFs, CRFs slowly release their nutrients, minimizing leaching and continually providing seedlings with nutrients throughout the growing season in a manner that parallels seedling nutrient demands (Goertz 1993). Generally CRFs have shown positive effects on tree seedling outplanting performance in forestry settings (Arnott and Burdett 1988; Fan et al. 2002; Jacobs et al. 2005; but also see Trubat et al. 2011; Oliet et al. 2013); their effectiveness in stimulating seedling growth and performance in reclamation sites remains unclear.

The successful restoration of forest ecosystems includes not only the establishment of a tree canopy but also an accompanying understory plant community. Understory plant 
species increase forest structure and function as they provide ecosystem services and contribute significantly to biodiversity (Nilsson and Wardle 2005; Macdonald et al. 2015a, b). While some understory species can be particularly beneficial on reclamation sites, early successional and ruderal species often dominate restoration areas and can severely compete with the planted tree species (Macdonald et al. 2015a). Generally, northern boreal forests are nutrient limited environments where nutrient amendments could favour nitrophilous grass and forb species which have rapid growth rates, large leaf areas and are significant competitors to both young trees and other native vegetation (Landhäusser and Lieffers 1998; Grainger and Turkington 2013; Hedwall et al. 2013). As a result, field fertilization of boreal forest ecosystems is controversial as it can lead to a decline in plant species richness (Grainger and Turkington 2013; Gilliam 2007) and uncertain tree growth responses.

Competition is a common threat to the establishment of planted seedlings during forest regeneration and restoration. Often these competitive conditions are driven by high resource availability, allowing competitors to proliferate and overwhelm the site, outcompeting newly planted seedlings. An argument has been made that producing planting stock with specific characteristics such as large size, high root to shoot ratios and high nutrient and carbon reserve status can potentially reduce or counter competitive conditions (Lamhamedi et al. 1998; Grossnickle 2012; Landhäusser et al. 2012a, b; Cortina et al. 2013). The loading of seedlings with nutrient reserves during nursery production has been hailed as a potential mechanism to mitigate competitive effects of vegetation on forest regeneration and restoration sites (Malik and Timmer 1996; Timmer 1996; Oliet et al. 2013). Nutrient loaded seedlings of different species have been shown to outperform conventional seedling stock and better cope with abiotic and biotic stress. These species include Picea mariana (Malik and Timmer 1996), Eucalyptus globulus (Close et al. 2005), Quercus ilex (Oliet et al. 2009), and Cunninghamia lanceloata (Xu and Timmer 1999) in forest regeneration after harvesting as well as Quercus alba and Quercus rubra in mine reclamation settings (Salifu et al. 2009). However, often the nutrient loading of seedlings can be confounded with changes in other seedling characteristics such as height, root collar diameter, and/or root to shoot ratio compared to unloaded seedling, which could complicate the association of observed growth responses with nutrient loading (Cuesta et al. 2010). The superior performance of nutrient loaded seedlings is thought to be due to increased translocation of nutrients to actively growing tissues (Malik and Timmer 1996), enhanced stress resistance (Timmer 1996), and increased root growth (Oliet et al. 2009) resulting in improved nutrient uptake from the soil (Malik and Timmer 1996). However, strong competitive conditions often occur on sites with already high nutrient and water resource levels; here the availability of nutrients for the planted seedlings might not be the limiting factor. Subsequently the use of nutrient loaded seedlings may actually be more valuable on nutrient limited sites where a higher internal nutrient status might give planted seedlings a growth advantage over other establishing species. In reclamation sites after surface mining, soils can greatly vary in nutrient availability and are often amended with fertilizers which have the potential to stimulate competing vegetation more than the seedlings (Xu and Timmer 1999; Sloan and Jacobs 2013).

Trembling aspen (Populus tremuloides) is the most widely distributed tree in North America and is regularly planted in large numbers on reclamation sites in Alberta. However, producing and obtaining quality aspen seedling stock is a continuing challenge (van den Driessche et al. 2003; Landhäusser et al. 2012a, b), and the outplanting success and performance of nutrient loaded aspen seedlings on field sites in response to field fertilization and the subsequent vegetation response has not been studied. Significant progress has been made to identify and modify seedling characteristics of aspen seedlings that influence aspen planting 
stock quality such as root to shoot ratio, terminal bud size, and reserve status (Landhäusser et al. 2012a, b). More recently, a study demonstrated that by inhibiting shoot growth, trembling aspen can be successfully nutrient loaded during nursery production while maintaining other seedling characteristics such as height and root to stem ratio (Schott et al. 2013). This was novel, as nutrient loading has most successfully been achieved in seedlings of species with determinate or periodic (rhythmic) growth strategies via exponential fertilization rather than in species with indeterminate growth strategies such as aspen.

In this study, we compare the potentially interacting effects of nutrient status of aspen seedling stock, field fertilization regime, soil type, and subsequent understory vegetation development on aspen seedling outplanting performance. We hypothesized that nutrient loaded seedlings would perform better than standard seedlings regardless of soil type, fertilizer regime, and competing vegetation.

\section{Methods}

\section{Site description}

This study was carried out on a large overburden dump structure $\left(56^{\circ} 57^{\prime} 41^{\prime \prime} \mathrm{N}\right.$, $111^{\circ} 18^{\prime} 49^{\prime \prime} \mathrm{W}$ ) located within Suncor Energy Inc.'s Millennium Mine oil sands lease. The mine site is located in the Central Mixedwood subregion of the Boreal Forest Natural Region of Alberta which is characterized by an undulating landscape that includes upland mixed forests of aspen, white spruce (Picea glauca), and jack pine (Pinus banksiana) with wetlands dominated by peatmoss (Sphagnum spp.) and black spruce (Picea mariana) fens (Natural Regions Committee 2006). Based on a 30 year record obtained from Environment Canada, the climate in the region has average daily temperatures ranging from $-18.8{ }^{\circ} \mathrm{C}$ in January to $16.8{ }^{\circ} \mathrm{C}$ in July with an annual average of $0.7{ }^{\circ} \mathrm{C}$. The average temperature during the April-September growing season is $11.7{ }^{\circ} \mathrm{C}$ while the average annual precipitation totals $456 \mathrm{~mm}$, of which $342 \mathrm{~mm}$ falls as rain. Over the 2 year period of this study, precipitation in the 2011 growing season totaled $238 \mathrm{~mm}$ and the average temperature was $12.2{ }^{\circ} \mathrm{C}$. From October 2011 to March 2012, $51 \mathrm{~mm}$ of precipitation fell as snow, and the average temperature was $-6.7^{\circ} \mathrm{C}$. During the 2012 growing season $350 \mathrm{~mm}$ of precipitation fell and the average temperature was $12.7^{\circ} \mathrm{C}$.

Soil capping materials used on the reclamation site were originally located and salvaged from within the footprint of the overburden dump. The FFM was composed of the top $30 \mathrm{~cm}$ of natural upland soil and included L-F-H horizons (forest floor), the mineral A horizon, and part of the B horizon of an Orthic Gray Luvisol (Soil Classification Working Group 1998). The remaining $B$ and upper part of the $C$ horizon to a soil depth of $60 \mathrm{~cm}$ (subsoil) was then stripped separately. Suitable deeper C horizon material (low sodic till) was then salvaged to a maximum depth of $3 \mathrm{~m}$. The PMM was derived from low-lying peatland sites with gleysolic soils, where the organic soil layer and underlying mineral soil were salvaged to a depth of $30 \mathrm{~cm}$. In 2009 , all salvaged materials were stockpiled separately for 2 years before being used as cover soil for the overburden dump in 2011.

\section{Experimental design}

In late 2009, the construction and contouring of the sodic overburden dump was completed and the landform surface was covered with a $1 \mathrm{~m}$ layer of the suitable C-horizon material (low sodic till). A 1.3 ha level area was selected on the landform to be capped with either 
Table 1 Average soil properties of forest floor-mineral mix (FFM) and peat-mineral mix (PMM) soil types measured in June 2011 before planting and fertilization

\begin{tabular}{lccc}
\hline & FFM & PMM & $p$ \\
\hline Sand $(\%)$ & 58.2 & 52.3 & 0.035 \\
Clay $(\%)$ & 13.8 & 14.2 & 0.921 \\
$\mathrm{pH}$ & 6.64 & 6.67 & 0.858 \\
Conductivity $\left(\mathrm{dS} \mathrm{m}^{-1}\right)$ & 0.139 & 0.125 & 0.229 \\
\hline
\end{tabular}

FFM or PMM. For the FFM cap, the low sodic till was covered with $30 \mathrm{~cm}$ of the salvaged subsoil followed by $20 \mathrm{~cm}$ of FFM. For the PMM cap, the low sodic till was covered with a $50 \mathrm{~cm}$ layer of PMM (Table 1). Surface soil placement began in August 2010 and was completed by early June 2011.

The experimental design was a blocked split-split-plot design with 5 replications, where the FFM and PMM capping soils were placed in large $45 \mathrm{~m}$ wide strips across the overall research area. Plots $(40 \times 65 \mathrm{~m})$ were selected in a way that one half of the plot contained FFM material and the other half PMM capping material (each $20 \mathrm{~m}$ wide $\times 65 \mathrm{~m}$ long). Four fertilizer regimes (first split) were superimposed on the soil type treatments by dividing each strip into four $15 \mathrm{~m}$ by $15 \mathrm{~m}$ fertilizer treatment plots. The plot size allowed for a $5 \mathrm{~m}$ wide buffer between plots to spatially separate potential changes in soil types and fertilizer regimes. The four fertilizer regimes (see below) were randomly assigned to these plots within each soil type treatment.

The four field fertilization regimes were: (1) a high application rate of an immediately available fertilizer (High IAF; $500 \mathrm{~kg}$ fertilizer ha ${ }^{-1}$ ); (2) a low application rate of an IAF (Low IAF; $250 \mathrm{~kg}$ fertilizer $\mathrm{ha}^{-1}$ ); (3) a high application rate of a controlled-release fertilizer (CRF; $670 \mathrm{~kg}$ of fertilizer $\mathrm{ha}^{-1}$ ); and (4) an unfertilized Control. The IAF was a 20-20-20 N-P-K water soluble Peters General Purpose fertilizer, while the CRF was a 15-9-12 N-P-K granular Osmocote Plus fertilizer with an 8-9 month release period. Both products contain a mixture of chelated micronutrients and are produced by The Scotts Company LLC (Marysville, OH, USA). Fertilizers were applied once by hand using an EarthWay Ev-N-Spread hand held seeder (Bristol, IN, USA) from June 28-30, 2011. Plots assigned to the High IAF regime were fertilized at a rate of $11.25 \mathrm{~kg}$ fertilizer per $15 \mathrm{~m} \times 15 \mathrm{~m}$ plot; Low IAF plots received half of the previous fertilization rate (i.e. $5.625 \mathrm{~kg}$ per plot); and the CRF treated plots received $15.1 \mathrm{~kg}$ fertilizer per plot, resulting in a nitrogen application rate equivalent to the High IAF regime.

Permanent tree measurement plots (second split) were centered within each fertilization plot to include a total of 36 tree seedlings, 18 nutrient loaded and 18 standard seedlings. In May 2011, tree seedlings were planted in 12 alternating rows of standard and nutrient loaded seedlings at $1.3 \mathrm{~m}$ spacing resulting in a planting density of 6000 stems ha ${ }^{-1}$. Seedlings were measured for growth performance in 2011 and 2012.

\section{Production and outplanting of aspen seedling stock}

For this study, aspen planting stock was grown under two different sets of conditions resulting in a standard and a nutrient loaded seedling stock. All seedlings were sown and grown in Styroblock containers (5-12A (220 ml), Beaver Plastic; Edmonton, Alberta, Canada) for one growing season at Smoky Lake Nursery (Smoky Lake, Alberta, Canada $54^{\circ} 6^{\prime} \mathrm{N} ; 112^{\circ} 28^{\prime} \mathrm{W} ; 598 \mathrm{~m}$ a.s.1.). Planting stock production followed the protocols 
developed for producing nutrient loaded aspen (Schott et al. 2013). Briefly, seedlings were grown from open-pollinated, Fort McMurray sourced seed $\left(56^{\circ} 39^{\prime} 0^{\prime \prime} \mathrm{N}, 111^{\circ} 13^{\prime} 0^{\prime \prime} \mathrm{W}\right)$ sown on March 26, 2010 into cavities filled with peat and perlite (9:1, by volume). Standard greenhouse growing conditions for aspen (temperature: $21{ }^{\circ} \mathrm{C}$ average, max $28{ }^{\circ} \mathrm{C}$, min $18{ }^{\circ} \mathrm{C}$; relative humidity: $>70 \%$ ) were used to germinate and establish the aspen seedlings. Seedlings were fertigated with a balanced nutrient fertilizer $\left(78 \mu \mathrm{g} \mathrm{g}^{-1} \mathrm{~N}\right.$, $77 \mu \mathrm{g} \mathrm{g}^{-1} \mathrm{P}, 161 \mu \mathrm{g} \mathrm{g}^{-1} \mathrm{~K}, 46 \mu \mathrm{g} \mathrm{g}^{-1} \mathrm{~S}$, and a balanced blend of chelated micronutrients) which were included in every watering with an automated mist irrigation system until May 12, 2010, at which point seedlings were moved outside. On June 24, all seedlings were thoroughly watered with a solution containing $5 \mathrm{~mL} \mathrm{~L}-1$ of the shoot growth inhibitor Bonzi $^{\circledR}$ (containing $4 \mathrm{~g} \mathrm{L-1}$ of the active ingredient paclobutrazol; Syngenta, North Carolina, USA.). Regular fertigation continued until seedlings had set bud (July 12). On that date the seedlings were separated into two treatments: standard and nutrient loaded. Standard feed seedlings continued to receive the same fertilizer concentration while nutrient concentrations were doubled for nutrient loaded seedlings $\left(156 \mu \mathrm{g} \mathrm{g}^{-1} \mathrm{~N}\right.$, $154 \mu \mathrm{g} \mathrm{g}^{-1} \mathrm{P}, 322 \mu \mathrm{g} \mathrm{g}^{-1} \mathrm{~K}, 92 \mu \mathrm{g} \mathrm{g}^{-1} \mathrm{~S}$, and twice the chelated micronutrient concentration). Fertigation was continued at these levels until September 4, after which all fertigation ceased for all seedlings and seedlings were only watered as necessary. The seedlings were allowed to naturally go dormant and harden while remaining outside. In November 2010 seedlings were lifted, bagged, and stored frozen $\left(-3{ }^{\circ} \mathrm{C}\right)$ in waxed cardboard boxes until June 2011. Both seedling stock types were similar in height, root collar diameter, and root to stem ratio (Table 2, all $p>0.443$ ).

Foliar samples $(n=5)$, each consisting of pooled leaves from 10 seedlings, were collected in late summer of 2010 from the upper $10 \mathrm{~cm}$ of seedlings of both standard and nutrient loaded seedlings at the nursery. All samples were washed with de-ionized water, dried to constant mass at $70{ }^{\circ} \mathrm{C}$ for 2 days in an oven and ground to a fine powder in a Wiley Mill (Thomas Scientific; Swedesboro, NJ, USA) passing 40-mesh (0.4 mm). Total N concentration of foliar tissue samples was determined by Kjeldahl digestion (Kalra and Maynard 1991). Concentrations of P, K, and S were determined by inductively coupled plasma optical emission spectrometry (ICP-OES) after microwave digestion (EPA Method 3051, US Environmental Protection Agency; Washington, DC). Seedlings in the nursery showed significantly higher concentrations of $\mathrm{N}, \mathrm{P}, \mathrm{K}$, and $\mathrm{S}$ in the leaves of nutrient loaded seedling stock type which are known to correlate well with stem and root tissue nutrient concentrations in dormant seedlings (Schott et al. 2013) (Table 2).

In August 2011, tree seedling mortality, height, and root collar diameter were measured for each of the 36 seedlings in each tree measurement plot and in August 2012 only mortality and height measurements were taken. In order to calculate early seedling dry mass and resource allocation above and belowground, in August of 2011 two seedlings of each stock type that had the approximately average height of the measured seedlings were carefully excavated in each treatment plot (but outside the seedling plot), placed into plastic bags, and stored frozen. Leaves, including petioles, were removed from stems and the stem and root tissues were separated. All tissues were oven dried at $70{ }^{\circ} \mathrm{C}$ to constant mass and weighed to determine leaf, stem, and root dry weights. Dried root weights were divided by dried stem weights to calculate the root to stem ratio (RSR).

\section{Available soil nutrients}

Initial soil characteristics were determined for each soil type by collecting two samples from the top $20 \mathrm{~cm}$ of soil from each of the 40 plots (Table 1). Samples were analyzed for 
Table 2 Average height, root collar diameter, root:stem ratio, and foliar nutrient concentrations (standard deviation) of standard and nutrient loaded aspen seedling stock types $(\mathrm{n}=10)$

\begin{tabular}{lclr}
\hline & \multicolumn{2}{l}{ Stock type } & \multirow{2}{*}{$p$} \\
\cline { 2 - 3 } & Standard & Nutrient loaded & \\
\hline Height $(\mathrm{cm})$ & $41.0(7.6)$ & $43.5(7.8)$ & 0.471 \\
Root collar diameter (mm) & $4.9(0.71)$ & $4.7(0.47)$ & 0.443 \\
Root:stem ratio & $3.57(0.55)$ & $3.58(0.48)$ & 0.979 \\
$\mathrm{~N}\left(\mathrm{mg} \mathrm{g}^{-1}\right)$ & $18.9(1.3)$ & $27.0(1.6)$ & $<0.001$ \\
$\mathrm{P}\left(\mathrm{mg} \mathrm{g}^{-1}\right)$ & $2.73(0.04)$ & $3.17(0.04)$ & $<0.001$ \\
$\mathrm{~K}\left(\mathrm{mg} \mathrm{g}^{-1}\right)$ & $5.02(0.58)$ & $8.46(0.42)$ & $<0.001$ \\
$\mathrm{~S}\left(\mathrm{mg} \mathrm{g}^{-1}\right)$ & $2.06(0.31)$ & $2.45(0.31)$ & 0.013 \\
\hline
\end{tabular}

texture, conductivity, and $\mathrm{pH}$. Soil texture measures were calculated from hydrometer readings used to determine percent total clay $(<2 \mu \mathrm{m})$, silt $(2-50 \mu \mathrm{m})$, and sand $(>50 \mu \mathrm{m})$ (Carter and Gregorich 2006). The $\mathrm{pH}$ and electrical conductivity were measured on a filtered extract from a slurry of 1 part dry soil mixed with two parts de-ionized water (by volume) that was allowed to stand with occasional stirring for 30-60 min (Carter and Gregorich 2006).

Soil nutrient supply during the experiment was determined using Plant Root Simulator (PRS) probes (Western Ag Innovations Inc.; Saskatoon, Canada). Individual probes consist of a $10 \mathrm{~cm}^{2}$ ion exchange resin membrane surrounded by a plastic frame and handle and were used in pairs consisting of one anion probe and one cation probe. In both 2011 and 2012, two burials [June 8-July 26 (49 days) and July 26-September 6 (42 days)] were used to avoid probe saturation and minimize any degradation of the accumulated nutrients by soil microbes. The data from the two burials was later pooled to represent availability of soil nutrients over the growing season as a whole. Each burial consisted of four pairs of probes; two pairs at opposite corners of the permanent tree measurement plots. In 2011 two samples (each consisting of one anion and one cation probe) were analyzed per plot for a total of 80 samples/burial period, while in 2012 (when soil nutrient supply had decreased without additional fertilizer input) all probes in each subplot were analyzed together for a total of 40 samples/burial period. Upon removal, excess soil was removed and PRS probes were placed in sealable plastic bags and stored in a cooler for less than $4 \mathrm{~h}$ before being moved to a refrigerator where probes were stored for a maximum of 4 days until cleaning. To determine nutrient supply rates, the ions were first desorbed off the ion-exchange membrane using $0.5 \mathrm{~N}$ HCL. The resulting eluate was colorimetricaly analyzed for $\mathrm{NO}_{3}{ }^{-}$and $\mathrm{NH}_{4}{ }^{+}$, atomic absorption inductively-coupled plasma spectrometry measured $\mathrm{P}$, $\mathrm{Ca}, \mathrm{Mg}, \mathrm{Fe}, \mathrm{Zn}, \mathrm{Mn}, \mathrm{Cu}, \mathrm{Al}, \mathrm{Pb}$, and $\mathrm{Cd}$, and $\mathrm{K}$ concentration results were obtained via flame emission.

\section{Field vegetation assessments}

Initial vegetation development was assessed in two one-square meter sampling quadrats which were set up in the centre of each treatment plot. Sampling of the 80 vegetation plots took place August 22-23, 2011, July 27-28, 2012, and July 30-31, 2013. During each assessment, individual plant species were identified and their percent cover was estimated. Percent cover was measured to the nearest $1 \%$ if less than $10 \%$ and to the nearest $5 \%$ if greater than $10 \%$ cover (Macdonald et al. 2015a). 
Percent cover of individual species (averaged based on two quadrats) and cover by functional group (sum of individual species cover for trees, shrubs, forbs, and graminoids) were used to compare between years. When possible, species were identified in the field during the assessments; however, if exact species identification was not possible in the field, the specimen was collected, pressed, given a descriptive name, and brought back to the lab for identification.

\section{Statistical analyses}

Tree seedling performance was analyzed as a blocked split-split-plot design with 5 replications to determine the effects of aspen stock type (nutrient loaded or standard seedlings), soil type (FFM and PMM) and fertilizer application (High and Low IAF, CRF, and Control) on outplanting performance. Project block was analyzed as a random variable and there was no significant effect of block on any parameter. All interactions were considered in the statistical analysis (Table 3). The seedling performance measures used were seedling height growth (final height minus initial height), root collar diameter, root to stem ratio (RSR), and dry weights of foliar, stem and root components. All response

Table 3 ANOVA tables for aspen seedling height growth in the first (2011 [a]) and second (2012 [b]) field growing seasons showing degree of freedom (Df), sum of squares (Sum Sq), mean square error (Mean Sq), F and $p$ values $(\mathrm{n}=5)$

\begin{tabular}{lrrrrr}
\hline & Df & Sum Sq & Mean Sq & F & $p$ \\
\hline$a$ & & & & & \\
Block & 4 & 202.25 & 50.56 & 1.286 & 0.407 \\
Substrate & 1 & 375.04 & 375.04 & 9.536 & 0.037 \\
Ea & 4 & 157.31 & 39.33 & & \\
Fertilizer & 3 & 905.99 & 302.00 & 36.85 & $<0.001$ \\
Substrate $\times$ fertilizer & 3 & 75.15 & 25.05 & 3.057 & 0.048 \\
Eb & 24 & 196.69 & 8.20 & & \\
Stock type & 1 & 401.97 & 401.97 & 27.1975 & $<0.001$ \\
Stock type $\times$ substrate & 1 & 16.71 & 16.71 & 1.131 & 0.296 \\
Stock type $\times$ fertilizer & 3 & 22.23 & 7.41 & 0.501 & 0.684 \\
Stock type $\times$ substrate $\times$ fertilizer & 3 & 29.73 & 9.91 & 0.670 & 0.576 \\
Ec & 32 & 472.95 & 14.78 & & \\
$b$ & & & & & \\
Block & 4 & 357.3 & 89.3 & 1.779 & 0.295 \\
Substrate & 1 & 3627.8 & 3627.8 & 72.260 & 0.001 \\
Ea & 4 & 200.8 & 50.2 & & \\
Fertilizer & 3 & 912.1 & 304.0 & 4.343 & 0.014 \\
Substrate $\times$ fertilizer & 3 & 434.8 & 144.9 & 2.070 & 0.131 \\
Eb & 1 & 1680.3 & 70.0 & & \\
Stock type & 1 & 146.6 & 141.2 & 19.998 & $<0.001$ \\
Stock type $\times$ substrate & 3 & 17.2 & 5.7 & 18.178 & $<0.001$ \\
Stock type $\times$ fertilizer & 15.5 & 5.2 & 0.711 & 0.553 \\
Stock type $\times$ substrate $\times$ fertilizer & 3 & 258.0 & 8.1 & & 0.595 \\
Ec & & & & & \\
\hline & 3 & & & \\
\hline
\end{tabular}


variables met the assumptions of homoscedasticity and normality. Analyses were performed using the ssp.plot function in the agricolae package in $\mathrm{R}$ 3.0.2 ( $\mathrm{R}$ Core Team; Vienna, Austria).

$\mathrm{T}$ tests were performed using the univariate procedure to compare pre-planting seedling and soil characteristics. Repeated measures ANOVAs were used to compare 2011 and 2012 height growth. These analyses were done using PROC MIXED and PROC REG in SAS 9.2 (SAS Institute; Cary, NC, USA).

Plant community development was analyzed similarly except that due to well documented differences in vegetation development between the two soil capping materials (Mackenzie and Naeth 2010), each material was analyzed separately to determine the influence of fertilizer regimes and time on total understory vegetation cover development and the proportional cover of different functional groups. Linear regression analyses were used to relate seedling growth and percent cover of understory species to pooled soil nutrient supply rates for each year (PROC MIXED and PROC REG in SAS 9.2). Differences were considered statically significant at an $\alpha<0.05$.

\section{Results}

Seedling mortality averaged $4.8 \%$ over the 2 years of the study and was not significantly influenced by any of the treatments in either year (all $p$ values $\geq 0.28$ ). Seedling height growth, RCD, and root, stem, and leaf dry weights variables all responded similarly to the fertilizer and soil type treatments. After the first growing season, height growth, root collar diameter (RCD), and root, stem, and leaf dry weights were all greater in nutrient loaded seedlings than standard seedlings. However, the overall improved above ground performance in the nutrient loaded seedlings resulted in lower root to stem ratios than in the standard seedlings (Table 4).

After the second growing season, height growth of nutrient loaded seedlings (across all treatments) was still greater than standard seedlings $(p<0.001)$. However, this response was driven by the nutrient loaded seedlings when growing in PMM, while growth was not different between the two stock types when growing in FFM, resulting in a significant soil type by stock type interaction in the second growing season $(p<0.001$; Table $3 b$; Fig. 1$)$.

Table 4 Average (standard error of the mean) morphological characteristics of nutrient loaded and standard aspen seedling stock after the first growing season since outplanting (2011)

\begin{tabular}{llrr}
\hline & \multicolumn{2}{l}{ Stock type } & $p$ \\
\cline { 2 - 3 } & Nutrient loaded & Standard & \\
\hline Height growth $(\mathrm{cm})$ & $22.49(0.89)$ & $18.10(0.80)$ & $<0.001$ \\
Root collar diameter $(\mathrm{mm})$ & $8.52(0.17)$ & $6.94(0.13)$ & $<0.001$ \\
Root dry weight $(\mathrm{g})$ & $8.33(0.31)$ & $6.15(0.24)$ & $<0.001$ \\
Stem dry weight $(\mathrm{g})$ & $7.87(0.38)$ & $4.96(0.21)$ & $<0.001$ \\
Leaf dry weight $(\mathrm{g})$ & $5.47(0.37)$ & $3.40(0.19)$ & $<0.001$ \\
Root:stem ratio & $1.09(0.03)$ & $1.27(0.04)$ & $<0.001$ \\
\hline
\end{tabular}

Data were pooled across fertilizer regime and soil type to isolate the effect of stock type. Root collar diameter and height growth were measured on a subsample of 18 aspen seedlings in the field within a plot, while all other characteristics were measured on a subsample of four seedlings in each plot $(n=5)$ 

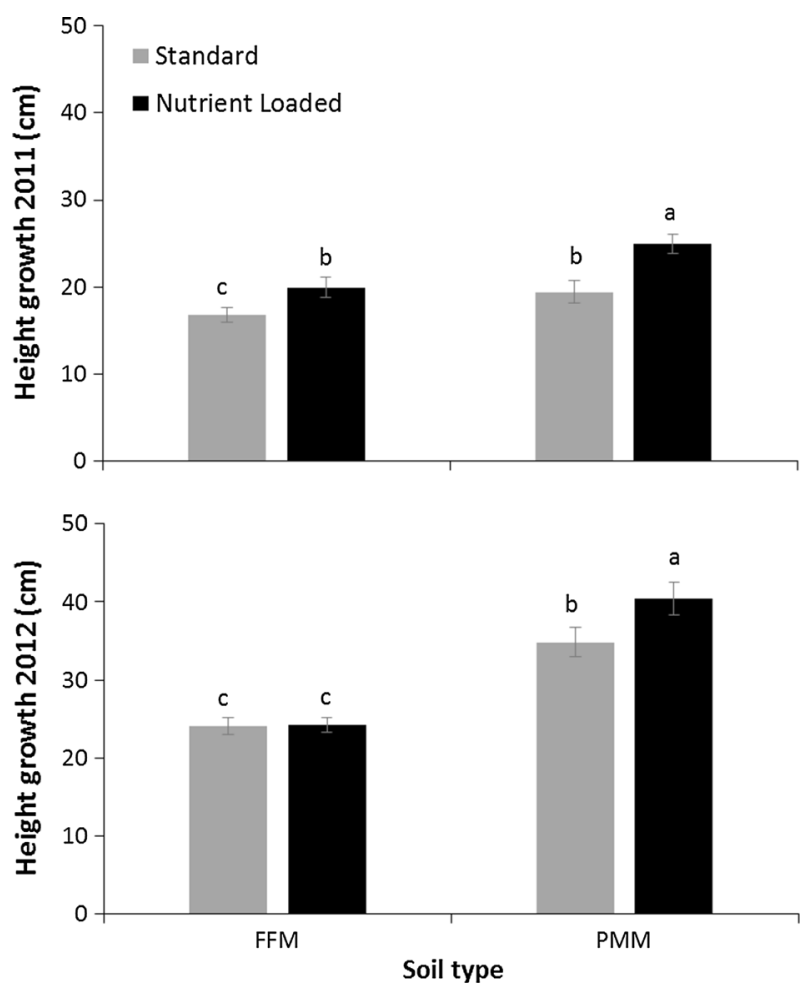

Fig. 1 Average height growth of outplanted standard and nutrient loaded seedlings grown on forest floormineral mix (FFM) and peat-mineral mix (PMM) soil types in 2011 (a) and 2012 (b). Error bars are standard error of the mean $(n=5)$

Across all fertilizer regimes and stock types, aspen seedlings had greater height growth in PMM than in FFM and this difference became larger in 2012, increasing from $21 \%$ in 2011 to $56 \%$ difference in 2012 (Fig. 2). In the first year, height growth of seedlings when unfertilized was not different between the two soil types, but when fertilized, seedling growth was greater in seedlings growing in PMM resulting in a significant soil by fertilizer interaction ( $p=0.021$; Fig. 2a).

Stock types responded similarly to the fertilizer applications with improved height growth in the first growing season. Fertilization with IAFs produced the greatest growth response in the first growing season, followed by the CRF, and then the unfertilized Control ( $p<0.001$; Fig. 2a). There was no difference in first growing season growth between the High and Low IAF. After the second growing season, height growth was only greater than Control in the CRF treatment, while there were no significant differences between High IAF, Low IAF, and/or Control treatments $(p<0.001)$. Root to stem ratio was the highest in the Control (1.39) followed by CRF (1.22), and IAF (Low 1.08 and High IAF 1.03$)$ but was not significantly affected by soil type $(p=0.140)$.

Soil N supply in the first growing season was greater in PMM than FFM and in the High IAF treatment, followed by Low IAF, CRF, and the unfertilized Control (Table 5). During the second growing season, there was no significant difference in soil $\mathrm{N}$ supply by fertilizer regime or soil type. Soil P supply was 10 times higher in the High IAF and 5 times higher 

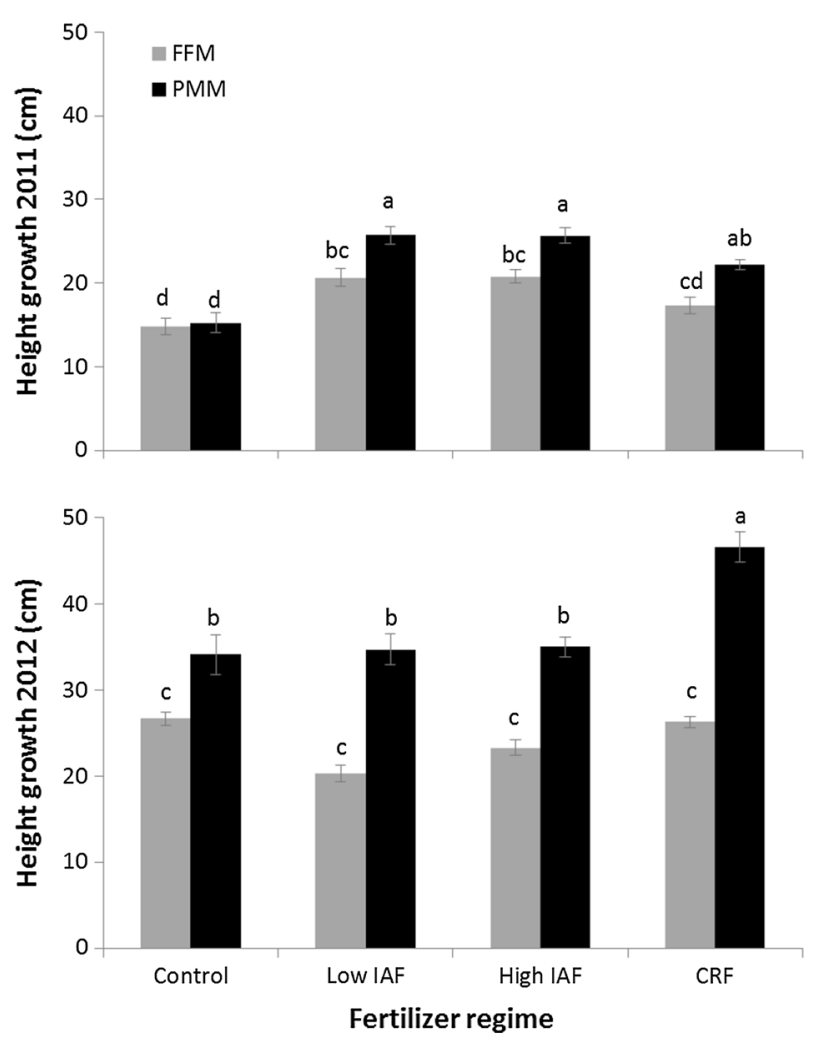

Fig. 2 Average height growth of outplanted seedlings on forest floor-mineral mix (FFM) and peat-mineral mix (PMM) soil types fertilized with four different fertilization regimes, unfertilized (control), low rate of immediately available fertilizer (low IAF), high rate of immediately available fertilizer (high IAF), and controlled release fertilizer (CRF) in 2011 (a) and 2012 (b). Error bars are standard error of the mean $(\mathrm{n}=5)$

in the Low IAF treatment than the Control and CRF treatments. Soil P supply did not vary by either year $(p=0.21)$ or soil type $(p=0.521)$ (Table 5$)$. Soil K supply was significantly greater in FFM than PMM $(p<0.001)$, but did not differ by fertilizer regime $(p=0.188)$ or between growing seasons $(p=0.480)$.

Nutrient loaded seedlings consistently outperformed standard seedlings regardless of soil $\mathrm{N}$ supply in the first growing season (Fig. 3a). The relationship between seedling height growth and soil $\mathrm{N}$ supply followed a saturation curve during the first growing season where height growth of seedlings did not increase above soil $\mathrm{N}$ supply rates of $450 \mu \mathrm{g}$ $10 \mathrm{~cm}^{-2} 91$ days $^{-1}$. During the second growing season, the soil $\mathrm{N}$ supply was much lower and the differences in $\mathrm{N}$ supply among treatments much narrower, but nutrient loaded seedlings still outperformed standard feed seedlings across the range of soil $\mathrm{N}$ supply rates. Seedling growth was not consistently related to soil P or K supply.

After the first growing season, total plant cover was greater in FFM (average $=45 \%$ cover) than PMM (average $=9 \%$ ) and cover increased with increasing fertility such that total cover was greater in the High IAF plots than Control plots (Fig. 4). In the second growing season, total cover of the two soil types was similar and the highest cover was 
Table 5 Average (standard error of the mean) of soil available N, P, and K by soil type [forest floormineral mix (FFM) and peat mineral mix (PMM)] and fertilizer regime [unfertilized (control), low rate of immediately available fertilizer (low IAF), high rate of immediately available fertilizer (high IAF), and controlled release fertilizer $(\mathrm{CRF})]$

\begin{tabular}{|c|c|c|c|c|c|c|c|}
\hline \multirow{2}{*}{$\begin{array}{l}\text { Soil } \\
\text { type }\end{array}$} & \multirow{2}{*}{$\begin{array}{l}\text { Fertilizer } \\
\text { regime }\end{array}$} & \multicolumn{2}{|l|}{$\mathrm{N}$} & \multicolumn{2}{|l|}{$\mathrm{p}$} & \multicolumn{2}{|l|}{$\mathrm{k}$} \\
\hline & & 2011 & 2012 & 2011 & 2012 & 2011 & 2012 \\
\hline \multirow[t]{4}{*}{ FFM } & Control & $40(11) \mathrm{c}$ & $12(1.5) \mathrm{a}$ & 4.1 (1.1) bc & $2.6(0.5) b$ & $118(26) b c$ & 110 (29) bc \\
\hline & Low IAF & $232(59) \mathrm{c}$ & $15(6.0) \mathrm{a}$ & $16(4.1) \mathrm{ab}$ & $6.8(1.4) \mathrm{b}$ & $238(72) \mathrm{a}$ & $162(51) b$ \\
\hline & High IAF & $639(86) \mathrm{b}$ & $23(8.8) \mathrm{a}$ & $27(6.8) \mathrm{a}$ & $18(4.8) a b$ & 190 (37) ab & $338(40)$ a \\
\hline & $\mathrm{CRF}$ & $196(61) c$ & $14(3.8) \mathrm{a}$ & $3.3(0.2) \mathrm{c}$ & $3.1(0.3) b$ & 137 (29) b & $132(40) b c$ \\
\hline \multirow[t]{4}{*}{ PMM } & Control & $41(23) \mathrm{c}$ & $25(7.8) \mathrm{a}$ & $2.2(0.2) \mathrm{c}$ & $1.2(0.2) \mathrm{b}$ & $14(2.7) \mathrm{d}$ & $14(2.5) \mathrm{c}$ \\
\hline & Low IAF & $746(228) b$ & $13(6.0) \mathrm{a}$ & $22(3.4) \mathrm{a}$ & $8.1(3.6) b$ & $27(3.9) \mathrm{d}$ & $24(2.1) \mathrm{c}$ \\
\hline & High IAF & 1459 (209) a & $11(2.9) \mathrm{a}$ & $23(9.9) \mathrm{a}$ & 33 (16) a & $43(9.4) \mathrm{cd}$ & $64(22) b c$ \\
\hline & $\mathrm{CRF}$ & 427 (120) bc & 31 (17) a & $2.9(0.7) \mathrm{c}$ & $3.2(0.6) \mathrm{b}$ & $33(16) \mathrm{d}$ & $37(7.8) \mathrm{c}$ \\
\hline$p$ & & $<0.001$ & 0.608 & $<0.001$ & 0.009 & $<0.001$ & $<0.001$ \\
\hline
\end{tabular}

Values are the sum of two plant root simulator probe measurements taken during the early season (early June to late July) and the late season (late July to early September) in both 2011 and 2012 expressed as $\mu \mathrm{g}$ $10 \mathrm{~cm}^{-2} 91$ days $^{-1}(\mathrm{n}=5) . p$ values represent the difference between soil types and letters within columns denote significantly different means between fertilizer regimes

associated with CRF plots (Fig. 4). During the third growing season, total cover did not differ between any of the treatments or from the previous year; although, there were differences in the proportion of cover of species groups. In the FFM, approximately $90 \%$ of the total cover was made up by forbs in 2011; however, forb cover decreased with each growing season to about $30 \%$ of the total cover in 2013 (year effect $p<0.001$ ), while the proportion of graminoids relative to the total cover increased from less than $10 \%$ of the total cover in 2011 to roughly $60 \%$ in 2013 (year effect $p<0.0001$, Fig. 5). This result was mainly driven by the application of fertilizer as the Control plots had significantly less graminoid cover than plots which received fertilizer in 2013. In the PMM neither year nor fertilizer regime impacted forb cover. Additionally, in the PMM plots tree and graminoid cover increased with time but these changes were not influenced by the fertilizer regime (Fig. 5).While plant cover and tree growth responded similarly to soil nutrient levels and fertilizer additions (Fig. 3b), seedling height growth of both seedling types was not directly related to competing plant cover across the soil type and fertilizer regime in either the first ( $p=0.737)$ or second $(p=0.688)$ growing season.

\section{Discussion}

Using nutrient loaded aspen seedlings improved early growth during the seedling establishment phase on reclamation sites. Nutrient loaded aspen seedlings had $19 \%$ (or $8 \mathrm{~cm}$ ) greater height growth than standard seedlings when averaged across all soil and fertilizer regimes after two growing seasons. Soil type also played a role where this difference was even greater for seedlings growing in PMM with a $21 \%$ (or $11 \mathrm{~cm}$ ) height growth increase; however, this could have also been related to competing vegetation development on these materials (discussed further below). These results are similar to other studies on the use of nutrient loaded seedlings which have shown increased seedling height, biomass, 


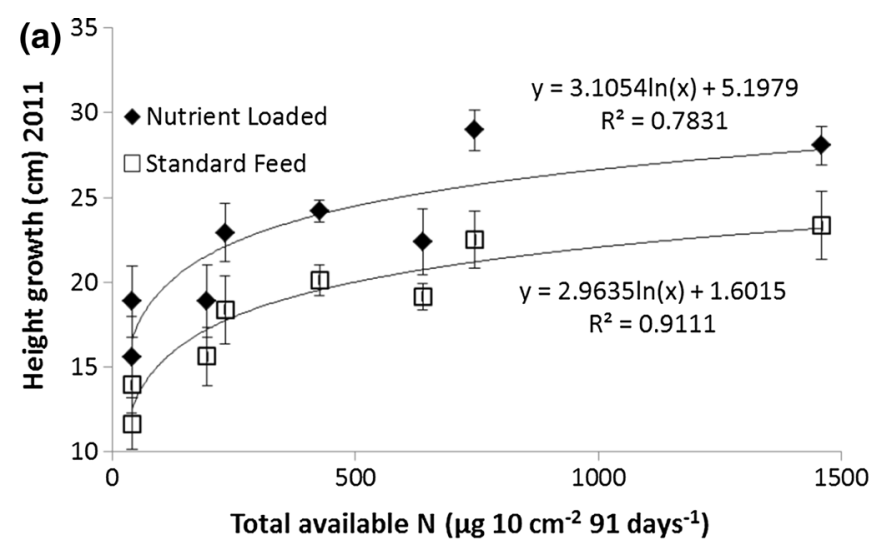

(b)

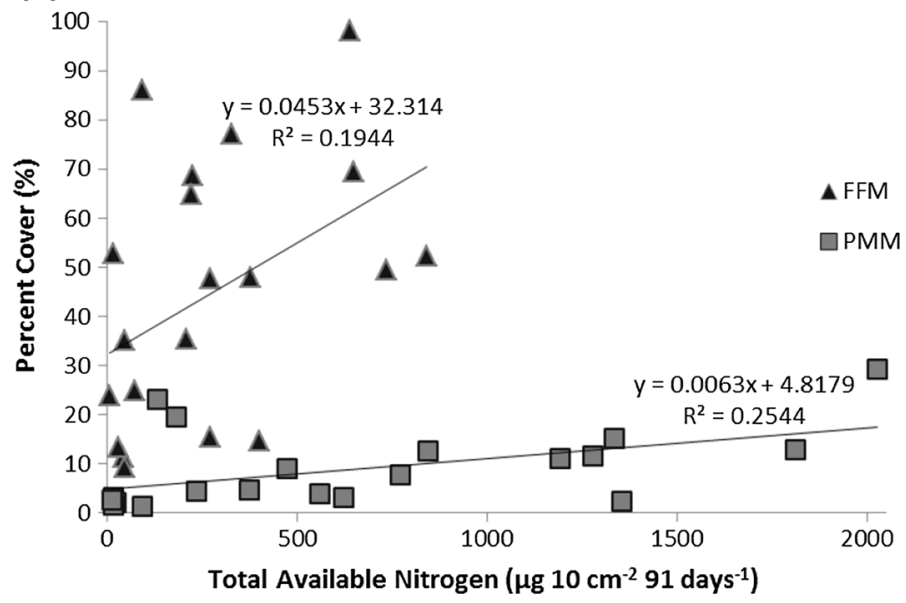

Fig. 3 Relationship between a average height growth $(\mathrm{cm})$ of outplanted standard and nutrient loaded seedlings $(\mathrm{n}=5)$ and $\mathbf{b}$ total vegetation cover on forest floor-mineral mix (FFM) and peat-mineral mix (PMM) soil types $(\mathrm{n}=20)$ and total soil available $\mathrm{N}$ in 2011. Total available $\mathrm{N}$ values [expressed as $\mu \mathrm{g}$ $10 \mathrm{~cm}^{-2} 91$ days $\left.^{-1}(\mathrm{n}=5)\right]$ are the sum of two plant root simulator probe measurements taken during the early (June 8-July 26) and the late growing season (July 26-September 6)

and root growth relative to standard seedlings (Malik and Timmer 1996; Xu and Timmer 1999; Oliet et al. 2009; Salifu et al. 2009). This is however, the first time nutrient loading has been tested with similar sized trembling aspen seedlings on different soil types and under different fertilization regimes in field conditions.

Growth response to fertilization paralleled the release rate of the different fertilizers with IAF resulting in the greatest height growth in the first outplanting season. Fertilizing with CRF had a longer lasting effect where seedlings continued to performed better in the second growing season than seedlings in the Control and IAF plots. This longer term tree growth response to CRF relative to IAF fertilization has also been observed in white spruce growing on a reclaimed mine site (Sloan and Jacobs 2013). The high (500 kg/ha) and low $(250 \mathrm{~kg} / \mathrm{ha})$ application rates of IAF tested in our study provided only first year height growth increases and both applications did not differ in any performance measure under 


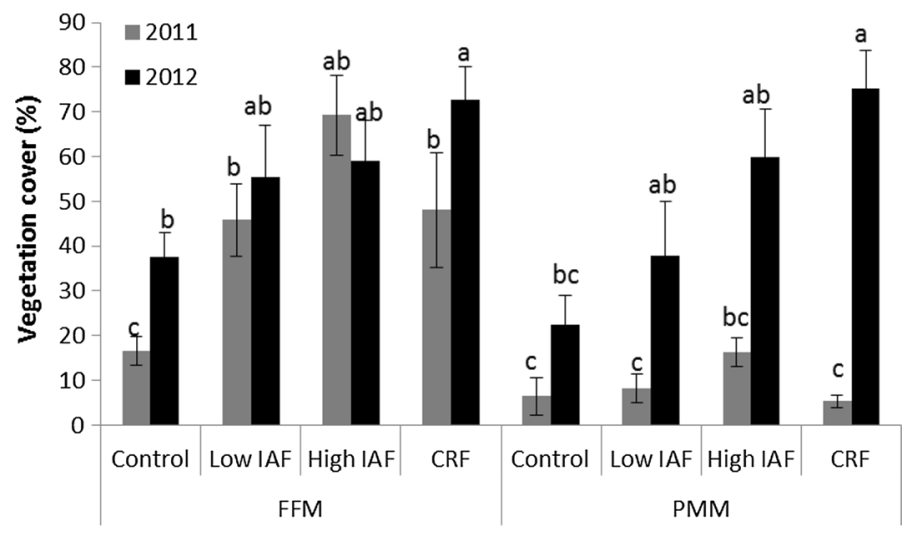

Fig. 4 Average total plant cover by fertilizer regime [unfertilized (Control), low rate of immediately available fertilizer (Low IAF), high rate of immediately available fertilizer (High IAF), and controlled release fertilizer (CRF)] in 2011 and 2012 cover on forest floor-mineral mix (FFM) and peat-mineral mix (PMM) soil types. Error bars are standard error of the mean $(\mathrm{n}=5)$

any conditions. This lack of growth response to a doubling of the fertilizer application rate indicates that broadcast fertilizing with high IAF rates during the early establishment period in tree plantations might not be beneficial to early tree seedling growth.

Seedlings growing in PMM overall outperformed seedlings in FFM, but the differences in growth response to the soil types were more pronounced when fertilized. This is consistent with the findings of Pinno et al. (2012) who observed that aspen established from seed in both PMM and FFM exhibited only minimal differences in height growth response with no fertilization, though the application of a combination NPK fertilizer resulted in seedlings showing better height growth responses in PMM than FFM. This may be due to the higher moisture holding and nutrient adsorption capacities of the PMM soil type, which had more mineral soil fines and organic matter, as compared to the FMM. These soil parameters may allow PMM to act as a buffer to water and nutrient loss, while retaining water and nutrients within the rooting zone of aspen seedlings for longer than FFM. Water availability is of particular importance when aspen seedling nutrition needs are met, as water and nutrients often co-limit aspen seedling growth; accordingly, an increase in one without an increase in the other may not translate to improved seedling performance (van den Driessche et al. 2003).

Better seedling performance on PMM; however, could also have been related to the slower development of a competing vegetation cover on this cover. The areas covered with FFM developed colonizing vegetation and with that competition for light and growing space much more rapidly in the first year than those covered with PMM, negating a positive nutrient loading growth response in the second growing season. Apart from the differences in nutrient tissue concentrations, our nutrient loaded seedlings did not differ morphologically from our standard seedlings (Table 2). Often seedling characteristics such as height and root to stem ratio are different between loaded and unloaded seedling stock types, which could confound growth responses formally attributed to nutrient loading, but actually are due to their different ability to cope with other competitive stresses (e.g. growing space and light) (Cuesta et al. 2010).

The rapid establishment of the colonizing vegetation on the FFM cover is likely a result of the seedbank in the FFM being comprised of a range of upland species compared to the 

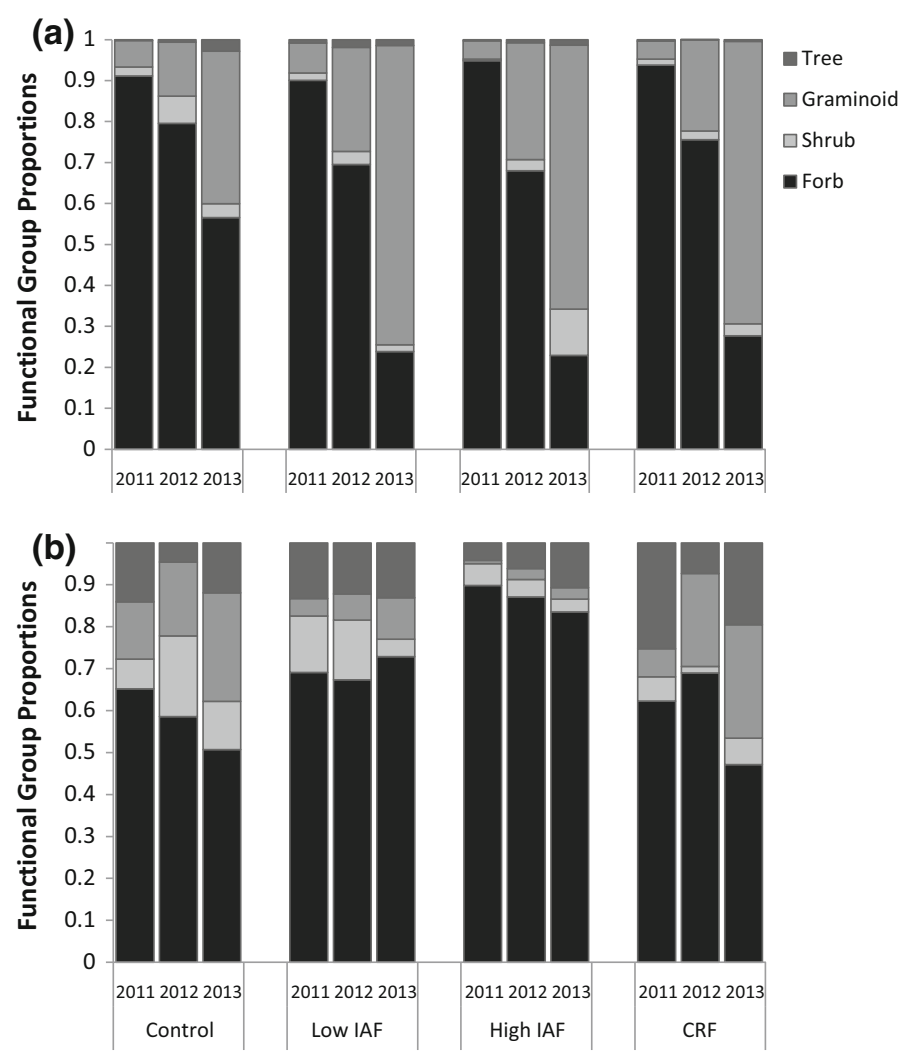

Fertilizer and Year

Fig. 5 Cover of functional groups as a proportion of total cover in a the forest floor-mineral mix (FFM) and b the peat-mineral mix (PMM) by fertilizer treatments [unfertilized (Control), low rate of immediately available fertilizer (Low IAF), high rate of immediately available fertilizer (High IAF), and controlled release fertilizer $(\mathrm{CRF})]$ in each year

PMM which would have been dominated by a lowland species seedbank that is less adapted to upland conditions (Snively 2014). While broadcast fertilization had a significant, albeit short-term, effect on seedling performance, it had a profound effect on the establishment, composition, and growth of the colonizing vegetation. Regardless of soil type, fertilization increased total plant cover. However, vegetation cover on FFM responded much stronger to fertilization than vegetation cover on PPM. Forest floor material is used as a preferred capping material for the establishment of forest understory vegetation during reclamation particularly when available and transferred directly from the salvage to the reclamation site. Although the one-time fertilization did not have a long lasting effect on the total vegetation cover in the FFM over that time period, fertilization increased the proportion of graminoids on FFM. By 2013, graminoids made up approximately $70 \%$ of the total plant cover in all of the fertilized plots in the FFM, while only contributing $37 \%$ of total cover in the Control plots. This change in vegetation composition has the potential for long-term impacts as dominant grasses can compete strongly with forbs and trees and can limit their establishment and growth (Sluis 2002; Dickson and 
Busby 2009). The most dominant graminoid in the fertilized plots was the native, perennial bunch grass, Agrostis scabra. This species does well on disturbed sites and, in particular, favours high nitrogen conditions (Tilman 1984). As a perennial, this species became established in 2011 when nutrient availability was greatest and then progressively became more dominant over time. Similarly to the FFM, total plant cover in the PMM plots increased with increasing total available nitrogen; however, due to the low initial total cover in the first growing season (5-16\%), significant differences between fertilizer treatments were not detectable. The low initial cover in 2011 could be attributed to the relatively small seed bank of the PMM capping material which in turn resulted in low initial establishment at the reclamation site (Snively 2014). The low relative graminoid cover in subsequent years in the PMM (27 \%), compared to the FFM, was also driven by fewer graminoid species found in the original PMM seed bank and potentially by a less suitable substrate for graminoid species which could have migrated onto the site.

Broadcast fertilization of reclamation sites early on appears to have mostly benefitted the non-target (non-forest understory) species which were contained in the existing soil seedbank (Snively 2014). Fertilization increased competing plant cover in both soil types and may negatively influence the longer term competitive balance on the site by favoring the development of a plant community dominated by graminoids, particularly on sites covered with FFM. This grass competition might have longer lasting effects on forest developmental trajectories by potentially producing relatively stable grass dominated sites creating conditions unsuitable for tree growth and forest canopy development (Landhäusser and Lieffers 1998). Supplying the extra nutrients either in the seedling tissue (e.g. nutrient loading) or localized near the planting spot (Sloan and Jacobs 2013; Sloan et al. 2016) might reduce this potential problem by reducing nutrient supply to the competition. Interestingly, a Low IAF application resulted in the same aspen seedling outplanting performance as the high IAF application on our sites, while CRF fertilization prolonged improved aspen seedling height growth into the second growing season. However, after two growing seasons, nutrient loaded seedlings performed similar or better than a standard seedling that was field fertilized (high or low) with the only exception of seedlings treated with CRF when growing in PMM. Therefore, planting nutrient loaded seedlings may allow for a reduction or the elimination of fertilizer use during early forest establishment, maintaining low nutrient conditions on the site, giving the less competitive but more stress tolerant (e.g. nutrient and light) forest understory species room to establish and to be maintained until a full forest canopy has developed. Broadcast application of fertilizers appears to be only marginally beneficial during the early establishment of forests on reclamation sites; therefore a reduction of these fertilizer inputs might have a greater benefit by reducing environmental impacts and costs. Fertilizer application at a later successional stage, however, once tree root systems and crowns have developed sufficiently, might expedite forest restoration and allow for a more efficient capture and cycling of the applied nutrients while the canopy continues to suppress the undesirable competitive but shade intolerant species which would otherwise take advantage of the higher nutrient availability.

Acknowledgments We thank the three anonymous reviewers for their helpful comments on improving the manuscript. Further we thank Pak Chow, Eckehart Marenholtz, Tyana Rudolfsen, Kate Melnik, Diana Young, Fran Leishman, and Philipp Leberer for laboratory and field assistance. Additionally, we are grateful to Francis Salifu and Suncor Energy for providing the site setup and facilitating site access. This study was supported by funding from Capital Power, Syncrude Ltd., Suncor Energy, Shell Canada, and the National Science and Engineering Research Council of Canada. 
Open Access This article is distributed under the terms of the Creative Commons Attribution 4.0 International License (http://creativecommons.org/licenses/by/4.0/), which permits unrestricted use, distribution, and reproduction in any medium, provided you give appropriate credit to the original author(s) and the source, provide a link to the Creative Commons license, and indicate if changes were made.

\section{References}

Alberta Government (1999) Conservation and reclamation information letter guidelines for reclamation to forest vegetation in the Athabasca oil sands region. $\mathrm{C}$ and R/IL/99-1.Gov. of Alberta, Edmonton, AB

Andersen CP, Bussler BH, Chanley WR, Pope PE, Byrnes WR (1989) Concurrent establishment of ground cover and hardwood trees on reclaimed mined land and unmined reference sited. For Ecol Manage 28:81-99

Arnott JT, Burdett AN (1988) Early growth of planted western hemlock in relation to stock type and controlled-release fertilizer application. Can J For Res 18:710-717

Carter MR, Gregorich EG (2006) Soil sampling and methods of analysis, 2nd edn. CRC Press, Taylor and Francis Group, Boca Raton, FL, USA

Casselman CN, Fox TR, Burger JA, Jones AT, Johns AT, John GM (2006) Effects of silvicultrual treatments on survival and growth of trees planted on reclaimed mine lands in the Appalachians. For Ecol Manage 233:403-414

Chang SX, Preston CM (2000) Understorey competition affects tree growth and fate of fertilizer $15 \mathrm{~N}$ in a coastal British Columbia plantation forest. Can J For Res 30:1379-1388

Close DC, Bail I, Hunter S, Beadle CL (2005) Effects of exponential nutrient loading on morphological and nitrogen characteristics and on afterplanting performance of Eucalyptus globulus seedlings. For Ecol Manage 205:397-403

Cortina J, Vilagrosa A, Trubat R (2013) The role of nutrients for improving seedling quality in drylands. New For 44:719-732

Cuesta B, Villar-Salvador P, Puertolas J, Jacobs DF, Benayas JMR (2010) Why do large, nitrogen rich seedlings better resist stressful transplanting conditions? A physiological analysis in two functionally contrasting Mediterranean forest species. For Ecol Manage 260:71-78

DesRochers A, van den Driessche R, Thomas BR (2003) Nitrogen fertilization of trembling aspen seedlings grown on soils of different pH. Can J For Res 33:552-560

Dickson TL, Busby WH (2009) Forb species establishment increases with decreased grass seeding density and with increased forb seeding density in a northeast Kansas, USA, experimental prairie restoration. Rest Ecol 17:597-605

Fan Z, Moore JA, Shafii B, Osborne HL (2002) Three-year response of ponderosa pine seedlings to controlled-release fertilizer applied at planting. West J Appl For 3:154-164

Gilliam FS (2007) The ecological significance of the herbaceous layer in temperate forest ecosystems. Bioscience 57:845-858

Goertz HM (1993) Controlled release technology. In: Howe-Grant M (ed) Encyclopedia of chemical technology, 4th edn. Wiley, New York, pp 254-274

Grainger TN, Turkington R (2013) Mechanisms for success after long-tern nutrient enrichment in a Boreal forest understory. PLoS ONE 8:e61229

Grossnickle SC (2012) Why seedlings survive: influence of plant attributes. New For 43:711-738

Hedwall PO, Nordin A, Strengbom J, Brunet J, Olsson B (2013) Does background nitrogen deposition affect the response of boreal vegetation to fertilization? Oecologia 173:615-624

Jacobs DF, Salifu KF, Seifert JR (2005) Growth and nutritional response of hardwood seedlings to controlled-release fertilization at outplanting. For Ecol Manage 214:28-39

Jacobs DF, Oliet JA, Aronson J, Bolte A, Bullock JM, Donoso PJ, Landhäusser SM, Madsen P, Peng S, Rey Benayas JM, Weber JC (2015) Restoring forests: what constitutes success in the 21st century? New For 46:601-614

Kalra YP, Maynard DG (1991) Methods manual for forest soil and plant analysis. Info Rep NOR-X319. Forestry Canada, Northwest Region, Northern Forestry Centre

Lamhamedi MS, Bernier PY, Hebert C, Jobidon R (1998) Physiological and growth responses of three sizes of containerized Picea mariana seedlings outplanted with and without vegetation control. For Ecol Manage 110:13-23

Landhäusser SM, Lieffers VJ (1998) Growth of Populus tremuloides in association with Calamagrostis canadensis. Can J For Res 28:396-401 
Landhäusser SM, Rodriguez-Alvarez J, Marenholtz EH, Lieffers VJ (2012a) Effect of stock type characteristics and time of planting on field performance of aspen (Populus tremuloides Michx.) seedlings on boreal reclamation sites. New For 43:679-693

Landhäusser SM, Pinno BD, Lieffers VJ, Chow PS (2012b) Partitioning of carbon allocation to reserves or growth determines future performance of aspen seedlings. For Ecol Manage 275:43-51

Macdonald SE, Quideau SA, Landhäusser SM (2012) Rebuilding boreal forest ecosystems after industrial disturbance. In: Dale Vitt D, Bhatti J (eds) Reclamation and restoration of boreal ecosystems: attaining sustainable development. Cambridge University Press, Cambridge

Macdonald SE, Snively AEK, Fair JM, Landhäusser SM (2015a) Early trajectories of forest understory development on reclamation sites: influence of forest floor placement and a cover crop. Rest Ecol 23:698-706

Macdonald SE, Landhäusser SM, Skousen J, Franklin J, Frouz J, Hall S, Jacobs DF, Quideau S (2015b) Forest restoration following surface mining disturbance: challenges and solutions. New For 46:703-732

Mackenzie DD, Naeth MA (2010) The role of the forest soil propagule bank in assisted natural recovery after oil sands mining. Rest Ecol 18:418-427

Malik V, Timmer VR (1996) Growth, nutrient dynamics, and interspecific competition of nutrient-loaded black spruce seedlings on a boreal mixedwood site. Can J For Res 26:1651-1659

Natural Regions Committee (2006) Natural regions and subregions of Alberta. Compiled by Downing DJ, Pettapiece WW. Government of Alberta, Edmonton, AB. Publ

Nilsson MC, Wardle DA (2005) Understory vegetation as a forest ecosystem driver: evidence from the northern Swedish boreal forest. Front Ecol Environ 3:421-428

Oliet JA, Tejada M, Salifu KF, Collazos A, Jacobs DF (2009) Performance and nutrient dynamics of holm oak (Quercus ilex L.) seedlings in relation to nursery nutrient loading and post-transplant fertility. Eur J For Res 128:253-263

Oliet JA, Puertolas J, Planelles R, Jacobs DF (2013) Nutrient loading of forest tree seedlings to promote stress resistance and field performance: a Mediterranean perspective. New For 44:649-669

Pinno BD, Landhäusser SM, MacKenzie MD, Quideau SA, Chow PS (2012) Trembling aspen seedling establishment, growth and response to fertilization on contrasting soils used in oil sands reclamation. Can J Soil Sci 92:143-151

Salifu KF, Jacobs DF, Birge ZK (2009) Nursery nitrogen loading improves field performance of barefoot oak seedlings planted on abandoned mine lands. Rest Ecol 17:339-349

Schott KS, Pinno BD, Landhäusser SM (2013) Premature shoot growth termination allows nutrient loading of seedlings with an indeterminate growth strategy. New For 44:635-647

Sloan JL, Jacobs DF (2013) Fertilization at planting influences seedling growth and vegetative competition on a post-mining boreal reclamation site. New For 44:687-701

Sloan JL, Uscola M, Jacobs DF (2016) Nitrogen recovery in planted seedlings, competing vegetation, and soil in response to fertilization on a boreal mine reclamation site. Forest Ecol Manage 360:60-68

Sluis WJ (2002) Patterns of species richness and composition in re-created grassland. Rest Ecol 10:677-684

Snively AEK (2014) Competitive relationships in forest restoration: Impact of cover crops and fertilization on tree and understory development. M.Sc. thesis, Department of Renewable Resources, University of Alberta, Edmonton, AB

Soil Classification Working Group (1998) The Canadian system of soil classification, 3rd ed. Agriculture and Agri-Food Canada, NRC Research Press, Ottawa, ON. Publ. 1646 (rev.)

Tilman GD (1984) Plant dominance along an experimental nutrient gradient. Ecology 65:1445-1453

Timmer VR (1996) Exponential nutrient loading: a new fertilization technique to improve seedling performance on competitive sites. New For 13:279-299

Trubat R, Cortina J, Vilagrosa A (2011) Nutrient deprivation improves field performance of woody seedlings in a degraded semi-arid shrubland. Ecol Eng 37:1164-1173

Van Cleve K (1973) Short-term growth response to fertilization in young quaking aspen. J For 71:758-759

van den Driessche R, Rude W, Martens L (2003) Effect of fertilization and irrigation on growth of aspen (Populus tremuloides Michx.) seedlings over three seasons. For Ecol Manage 186:381-389

Xu X, Timmer VR (1999) Growth and nitrogen nutrition of Chinese fir seedlings expose to nutrient loading and fertilization. Plant Soil 216:83-91 